\title{
Blowing in the wind? Identity, materiality, and the destinations of human ashes
}

\author{
David Prendergast Ethnographic Enterprises \\ JENNY HoCKey University of Sheffield \\ Le Onie Kellaher London Metropolitan University
}

\begin{abstract}
This article asks whether the recent UK-based practice of removing ashes from crematoria has led to entirely new, innovative rituals of disposal, or whether contemporary practice is an appropriation of late nineteenth-century Romantic values and beliefs. Drawing on findings from a major empirical study among both professionals and lay people involved in the removal of ashes, it explores the potentiality of ash remains as a mobile material residue of the corpse, and considers whether they enable disposal strategies which no longer reflect concerns with space and place - particularly those associated with traditional burial grounds.
\end{abstract}

\begin{abstract}
No, no. It's not like that. Death isn't romantic ... death is not anything ... death is ... not. It's the absence of presence, nothing more ... the endless time of never coming back ... a gap you can't see, and when the wind blows through it, it makes no sound.
\end{abstract}

Tom Stoppard, Rosencrantz and Guildenstern are dead (1968)

Stoppard's evocative stripping away of the cultural meanings through which human beings attempt to come to some kind of 'terms' with their mortality was published in the late 1960s. If his notion of 'the endless time of never coming back' resonated with audiences of that time, the 1970 s then saw the beginnings of new and apparently more deliberate meaning-making practices associated with death and dying in the UK. This article takes as its point of departure that moment of both disenchantment with traditional deathways, and initial engagement with new alternatives. Its focus is the post-1970s trend towards removing ashes from crematoria by survivors and it asks whether this spatial re-location constitutes a site of new and innovative ritualization.

\section{The study and its context}

The stimulus for the multiple-sited ethnographic study presented here was the shift away from conventional, collective sites of disposal, such as the crematorium grounds, the cemetery, and the churchyard, for the final disposal of ashes in the UK. Whereas 
only one in ten sets of ashes were removed from a crematorium by bereaved people in 1970 , by 2004 over 56 per cent of all cremated remains were being taken away for disposal elsewhere (Kellaher, Prendergast \& Hockey 2004). This now means that every year nearly a quarter of a million sets of ashes become a focus for decision-making by survivors of the deceased.

The 'freedoms' and forms of mobility which ashes now seem to represent were described during interviews conducted with professionals such as funeral directors, clergy, humanist officiants, bereavement counsellors, stonemasons, midwives, and council officials; and with bereaved people who have disposed of a relative's ashes. The study was carried out in the four sites chosen for Davies and Shaw's large-scale Reusing old graves survey (1995): the London borough of Barking and Dagenham, Nottingham, Sunderland, and Glasgow. These represent a wide distribution of urban locations throughout England and southern Scotland. In addition it was agreed with the authors of the original study that their primary data would be subjected to secondary analysis which promised to inform our core concern with finding out what people are doing with the ashes they remove, and how they understand and evaluate their choices. Gathered in 1995, Davies and Shaw's data also allow for a historical comparison of changing attitudes to death and disposal over the last decade in all four sites.

In every area, in-depth interviews were followed by focus groups with a minimum sample of seven professionals. This produced a sample of twenty-eight professionals, all of whom provided data on trends and practices within their areas. In addition, fifteen case studies with bereaved people who had chosen to remove ashes were completed in each of the four locations. Work among professionals helped with the recruitment of bereaved people, and preparation for the case study work we undertook with them. Based around an extended interview, case studies included ethnographic fieldnotes which described informants' homes, photographs, and copies of personal memorabilia. The overall sample of sixty bereaved informants encompasses a wide range of ages, social backgrounds, and relationship types. Distributed throughout four UK sites, this sample is not of a size suitable for predictive empirical generalization. What it allows is considerable insight into the cultural repertoires which inform the processes of private introspection and social negotiation that our informants have undertaken - and which result in particular disposal and memorialization strategies. Importantly, any interpretation of what our informants have described needs to take account of two key features of the cultural and legislative environment of cremation.

First, cremation is now the most common form of disposal in the UK, with an average rate of 66.5 per cent of all annual disposals, from the beginning of the 1970 s onwards. Since 2000, that average has peaked at 71.54 per cent (Kellaher et al. 2004). With almost three-quarters of the UK dead now being cremated, this form of disposal can be described as customary. Yet cremation itself was legalized comparatively recently, in 1884, following a legal test case and long period of lobbying by advocates such as Sir Henry Thompson, founder of the Cremation Society of Great Britain, and other dignitaries (Cremation Society of Great Britain 1974). The first UK crematorium was established in Woking in 1885 , with the number of UK crematoria increasing to almost 250 by 2004 .

While cremation was strongly promoted at the end of the nineteenth century, it remained uncommon until after the Second World War. This has been explained in terms of 'a diffuse, residual Christian sentiment [which] caused passive resistance to cremation' (Jalland 1999: 250). Indeed, Jalland cites the firm statement by Dr 
Wordsworth, Bishop of Lincoln, made in 1874, that cremation would undermine 'popular faith in the resurrection of the material body, leading to social revolution' (cited in Jalland 1999: 250). Only in the late 1960s did the prevalence of cremation outstrip that of burial. However, the last thirty years have seen another potentially important change - this time in the relationship between ashes and surviving friends and family. The incineration of the corpse is no longer a key point of physical separation between the dead and living, and while some survivors have always returned to the crematorium to visit a memorial plaque or Book of Remembrance entry, contemporary practices suggest a more materially engaged connection with the remains of the dead. Our project asks what this engagement might imply.

Second, the UK legislative environment within which ashes removed from a crematorium will then be disposed of is permissive compared with other European countries (Arber 2000). Not only does legislation permit their removal from crematoria, it also exercises no sanctions over their final destinations, assuming permission is granted by any landowner involved. By contrast, in Belgium, Denmark, Germany, Italy, Slovenia, and Sweden, regulations ensure that ashes normally remain at the cemetery or similar site of disposal. Only Finland, France, Spain, and the UK are without such regulations (see Arber 2000). The UK's relatively minimal legislative control gives survivors virtually unrestricted choice, though our informants sometimes described scattering or interring ashes surreptitiously, on the assumption that restrictive legislation is in place.

In sum, UK ash disposal policy and practice offer bereaved people freedom from the institutionalized times and places of death which for centuries bound the living and the dead together in community churchyards. With the popular acceptance of cremation during the second half of the twentieth century (Cremation Society 1974), a large majority of the dead acquired potential mobility, rather than being pinned down as whole bodies in the sacred, regulated space of the burial ground. This most materially grounded aspect of human existence, the death and deterioration of the body, now appears free from containment, its management cut loose from any fixed location. In making sense of contemporary practice, however, this article argues that the growth of cremation alone cannot explain the post-1970s trend towards more informal ash disposal, often outside institutional sites.

\section{The matter of materiality}

In seeking to unravel these spatial changes, the materiality of ashes merits consideration, particularly their 'dryness', which differentiates them from the 'wet' corpse (Danforth 1982; Hertz 1960 [1907]). This difference of substance has temporal implications which Hertz (1960 [1907]) alludes to in his account of the practice of double burial among the Dayak of Borneo. Drawing a parallel between burial and cremation, he says of cremation that,

far from destroying the body of the deceased, it recreates it and makes it capable of entering a new life ... the violent action of the fire spares the dead and the living the sorrows and dangers involved in the transformation of the corpse; or at least, it shortens that period considerably (1960 [1907]: 43).

In the altered substance of the ashes, the deceased rapidly acquires a 'new body', in Hertz's terms, one which is stable and beyond further deterioration.

Hertz's work informs the anthropology of the senses, in particular Howes's (1991) discussion of the way olfaction produces the experience of transition. Unlike sights or 
textures, smells are 'effusive' in that they escape form, are difficult to define, and can cling (Howes 1991: 140). Since it transcends boundaries, therefore, the smell of a decaying corpse creates the experience of transition, for, as Howes says, 'smells are ... ideally suited to expressing the notion of contagion or action at a distance. And the reason for this ... is that they are always "out of place", forever emerging from things, that is, crossing boundaries' (1991: 140). For Howes, death is a 'dirty business' (1991: 139) involving categorical ambiguity, the 'wet' corpse being neither of the living nor, yet, of the dead. However, he also quotes Hertz on the dryness of bone: ' $[T]$ he reduction of the corpse to bones, which are more or less unchangeable and upon which death will have no further hold, seems to be the condition and the sign of final deliverance' (cited in Howes 1991: 139). The connections made by Howes (1991) between a sensory or imaginative awareness of decay and the social and emotional experience of transition raises questions as to how the fast-tracking of bodily deterioration via incineration might, for example, influence the passage from being a wife to becoming a widow. If, as Huntington and Metcalf argue, 'the vitality of a culture or ideology depends upon its ability to channel the power of such mordant symbols as the corpse' (1979: 211), how might the materiality of ashes themselves symbolically resource different experiences of post-mortem transition?

Prothero (2001), in tracing the history of cremation in America from its late nineteenth-century beginnings, argues that traditionally the dangers associated with both societal decay following the death of the person and the material decay of their body have been met by combining extended cemetery visiting with embalming, plus burial in elaborate protective coffins. Preservation, both socially and physiologically, is the underlying strategy, he suggests. Cremation, by contrast, accelerates material decay, and survivors 'do not typically pray to the dead or expect the dead to contact them' (Prothero 2001: 5). Annihilation and banishment, in his view, are therefore the cremationist's goals, making this practice akin to burial as a way of sidestepping decay. However, Prothero goes on to suggest that by the 1920 and 1930 os crematoria operators recognized a market for attractive above-ground columbaria which offered niches for urns containing ashes - and which encouraged visiting. In an observation that is suggestive in terms of how the materiality of ashes might foster the experience of transition, he says of the 1930s: ' $\mathrm{I}] \mathrm{n}$ a nod to the customization of culture that would take hold in late-twentieth-century America, families were encouraged to personalize niches with photographs and decorate them with flowers' (Prothero 2001: 118).

As a residue of the corpse, ashes are therefore a tangible substance, yet one which resists rotting and bears little resemblance to the flesh. Arguably, ashes represent a highly ambiguous form of materiality, being of the person and of the corpse - and yet bearing little sensory resemblance to either. As a form of coarse dust, ashes have the quality of dryness which Hertz (1960 [1907]: 43) suggests can diminish the 'sorrows and dangers' that survivors experience as a corpse decays. Indeed, he also notes the 'deliverance' afforded by the corpse's eventual reduction to bone. None the less, as dust rather than bone, ashes are a fluid material which can be divided up, flung to the winds, strewn across the earth, or scattered into both the flow of a water course and the ebb of a tide. Ashes therefore have the formlessness and flow of a liquid, whilst being 'bone' dry. Ambiguous, both in their relationship with the materiality of the body, therefore, and in combining fluidity with utter desiccation, they offer survivors a potential symbolic form which conforms to Turner's classic account of any symbol's capacity for polysemy and multivocality: '[I]ts referents tend to cluster around opposite semantic 
poles. At one pole the referents are to social and moral facts, at the other to physiological facts' (Turner 1969: 48). As Prothero (2001) notes, in America cremation traditionally acted to banish both social and bodily decay. Yet for many of our informants, the ashes were, somehow, the body of someone they loved. Via incineration, however, they had been made to both transcend and condense the particularities of their previous bodily life. As such, they conform to the three meaning-making properties of symbols: condensation, unification of disparate referents, and polarization of meaning (Turner 1969: 48).

\section{Blowing in the wind?}

The dryness and fluidity of ashes are indeed qualities which our informants drew upon in informal disposal and memorialization practices. For example, in Glasgow, a busdriver scattered his best friend's ashes along their favourite walking route in Glencoe. Both the route and the memorial cairn built over the spot where the ashes were scattered provided a focus for remembrance. Another, northeastern English family accommodated relatives' and friends' diverse requests and agendas by dividing the ashes of their young son killed in a skiing accident, placing them in sites of memory such as the mountains where he climbed, his parental home, and a family plot in the cemetery. Thus dispersed, they became a focus for repeated private and public ceremonies. For the families of men who have served in the Navy, a ritual of 'burying' ashes in the sea in a casket is available; and for UK Hindu families, there is a move towards establishing ghats (waterside sites for the disposal of ashes). Indeed so common has water-borne disposal become that in response to 'regular requests from bereaved families', the Environment Agency has launched a public consultation about how it might act. ${ }^{1}$ The mobility of ashes is also exploited by people who deposit them in foreign locations or incorporate them within jewellery. A Nottingham schoolteacher described inadvertently spilling and partly ingesting ashes inside a car in transit to their final disposal. Significantly, the spilled portion was then rubbed into the car's upholstery, and other portions ground into the soft furnishings of the deceased's favourite pubs.

The practices our informants describe have occurred since 2000, yet neither the legislative environment of cremation nor the materiality of ashes have changed during this period. Even so, with the Christian belief in the centrality of bodily integrity for resurrection to eternal life no longer governing UK disposal practices (Horrox 1999), the need for a single site of disposal is receding. The waning of a consensus of religious belief is therefore important, though Prothero (2001) characterizes developments in America as re-ritualization, rather than secularization, a turn towards improvisation, informality, and simplicity within ritual practice since the late twentieth century. Similarly in the UK, changing spiritual, if not religious, orientations have a place alongside other aspects of its cultural history which may have produced an apparently radical departure from established practice. By contextualizing our data historically we not only draw attention to the social and technological changes which have enabled this departure, but also explore the cultural legacy, or repertoire, of images, values, and beliefs which may resource contemporary decision-making at the time of a death.

Walter (1990: 92-5) views the shift from burial to cremation as the UK's major means of disposal as compatible with a Protestant culture where the discarding of purgatory meant that the corpse's decay no longer provided a counterpart to the soul's transition 
to an afterlife. However, while Protestantism can be linked with scientific and bureaucratic rationality, with what Weber describes as the disenchantment of the everyday world (1930 [1904-5]), contemporary post-cremation ritualization might be seen as a form of re-enchantment which challenges Protestantism's rapid, unmediated postmortem meeting of 'man' with his 'maker'. Prothero similarly associates cremationism with the simplicity of American Puritanism, yet notes the later development of 'cremation as a preparation for memorialization' (2001: 196), 'a new era in American ritual life' (2001: 199) when the babyboomer generation made choice and personalization their guiding principles. His argument echoes the point made much earlier by Hertz, who says that cremation 'is usually neither a final act, nor sufficient in itself; it calls for a later and complementary rite' (1960 [1907]: 42).

In the UK, Walter's (1990) argument highlights links between the legalization of cremation in 1884 and the growth of a culture of scientific rationality from the nineteenth century onwards. By the 1970s, however, there was marked dissatisfaction with scientific explanations, and both Walter (1994) and Small (2001) interpret this period's new deathways as challenges to a modernist worldview. Post-cremation ritualization needs to be understood within this broader context, as an aspect of disposal and memorialization strategies which not only creates greater scope for the imagination and the emotions, but also demonstrates resistance to the principles of modernist rationality. The latter, we argue, had come to be found inadequate as a way of resolving what Hertz describes as the problematic, post-mortem 'opposition between the persisting image of a familiar person who is like ourselves and the image of an ancestor, who is sometimes worshipped and always distant' (1960 [1907]: 82). To what extent do our informants' choices echo the challenges to a modernist worldview which Walter (1994) and Small (2001) describe? Three kinds of decision-making processes are evident in our data.

First, there are negative choices, acts of resistance to traditional sites of disposal and associated modernist practices. Thus bereaved people were retaining their dead to avoid their additional loss into collective, sometimes badly maintained, depersonalizing sites; or to officialdom, institutional arrangements, and professional control.

Second, a decision may be deferred, following the removal of ashes from a crematorium at the suggestion of a funeral director or another family member. In such cases the person who was closest to the deceased may not know what to do with the ashes, particularly in the potential absence of traditional frameworks of belief or guidelines for practice. Equally, in the relative absence of traditional collective or consensual approaches, family members may not agree on a site or strategy of disposal - and nothing then happens. Ashes may also be removed in order subsequently to 'let them go' in a particular way, yet this painful moment may be deferred. And finally, ashes are removed from crematoria for future mingling with those of someone close, after their death, a strategy we go on to suggest may reflect a Romanticist worldview which contributed to nineteenth-century critiques of scientific rationality. Within the category of temporary 'choice', ashes are usually stored at the funeral director's premises or the survivor's home, sites which can become problematically permanent, if, for example, a funeral director's storage space becomes exhausted, or a survivor dies with ashes still in situ domestically.

Third, bereaved people may make positive choices which reflect their own wishes, or those of the deceased. Yet despite what Walter describes as 'the radical (postmodern) strand that truly believes in leaving it up to the individual to do it their own way' (1994: 
198), such choices may not be socially acceptable and adverse comments can produce an uncomfortable sense of having caused embarrassment.

\section{Continuing bonds?}

Having located our discussion of the materiality of ashes within the context of emergent trends in post-cremation ritualization, we now turn to a Euro-American therapeutic bereavement literature which developed across the twentieth century, following the work of Freud (1957 [1917]) and others of the psychoanalytic school. This literature has now challenged modernist beliefs and practices related to death. Crucially, we find a shift away from what Stroebe, Gergen, Gergen, and Stroebe (1996) called 'the breaking bonds hypothesis', that is, the therapeutic goals of the 1960s, 1970s, and 1980s, which emphasized 'coming to terms' with grief through letting the dead go (see Parkes 1972; Worden 1982). Groups such as parents bereaved of children (Riches \& Dawson 2000) and older widows (Littlewood 2001) had a central role here, asserting reluctance, indeed refusal, to part company with the dead (Small 2001). In contrast with the earlier 'breaking bonds hypothesis' (Stroebe et al. 1996), 'continuing bonds' became the new watchword, evidenced in the title of a much cited expert text which documents this claim (Klass, Silverman \& Nickman 1996).

Arguably this grass-roots critique has ushered in new therapeutic models of grief (Stroebe \& Schut 1999; Walter 1996) which valorize narrative, memorialization, and continuity. For example, Howarth's interviews with older widows revealed their experiences of their dead partners' persistent and welcome presence (cited in Hallam, Hockey \& Howarth 1999: 142-59). Bennett and Bennett (2000) similarly show the prevalence of experiences of the presence of the dead, as do Davies and Shaw (1995). Finally, Francis, Kellaher, and Neophytou (2000; 2001; 2005) document the relationships between the living and the dead which unfold via cemetery visits and the materialities of grave-tending and associated gardening practices.

In challenging the 'breaking bonds hypothesis', Stroebe et al. (1996) identify examples of how continuing bonds between the living and the dead have been sustained in more traditional societies and throughout the history of Western Europe. Noting that differences between the nineteenth and twentieth centuries have often been reduced to a stark contrast between 'romanticist' and 'modernist' worldviews, these authors suggest that in fact a 'romance with romanticism' (1996:38) persists into the late modern or postmodern present day, where, as noted, certain categories of bereaved people have robustly asserted their emotionally meaningful relationships with the dead. Stroebe et al.'s (1996) argument is supported by evidence of residual Romanticism percolating other domains of contemporary life. For example, during the intense urbanization of twentieth-century England and Wales, the 'green and pleasant land' represented by a shrinking southern English landscape became increasingly valorized. Macnaghten and Urry suggest that English Romanticism was a primary influence, citing Ousby's argument that 'the complex of responses we call Romanticism ... is still part of the intellectual climate we live in' (cited in Macnaghten \& Urry 1998: 176-7).

This raises the question of which elements of 'English Romanticism' might figure within the cultural repertoire of individuals who remove ashes from crematoria. Rugg's (1999) account of nineteenth-century mourning and memorialization practices highlights its core values of the uniqueness of the individual, intense emotional ties within the nuclear family, and the expression of powerful feelings at their death. She describes, for example, the first significant monument to the death of a child in the late eighteenth 
century, the subsequent memorialization of romantic bonds between husbands and wives via similar statuary, and the sanctioning of emotional outpourings within the natural landscape. As regards religious beliefs, the notion of heaven as a site at which God might be worshipped for eternity gave way to a view of heaven as a meeting place for lovers and family members who had 'gone before'. Rugg cites the popularity of prospective reunification in art and literature during this period: Rousseau's dying heroine Julie says to her lover: 'I do not leave you - I go to await you' (cited in Rugg 1999: 215); and Emily Brontë's Heathcliffe longs to be buried with his lover Cathy so that time can dissolve their bones into an eternal embrace.

While the notion of a linear historical chronology of cause and effect has been challenged (see Foucault 1977 [1969]), accounts such as Rugg's (1999) suggest a cultural repertoire of images, values, and beliefs which contemporary society's members inherit from the past. If we wish to understand how the 'romance with romanticism' which Stroebe et al. (1996: 38) describe has achieved current resonance, we can consider its location within a broader process of 're-enchantment' now argued to be taking place within contemporary society (Jenkins 2000). Jenkins defines enchantment as 'the human refusal to accept physical appearances as the sum total of the human world, which is manifest in many aspects of everyday life, from religion to literature' (2002: 5). Weber (1930 [1904-5]) argued that together monotheism and modernity inevitably brought the 'disenchantment of the world', and Willis and Curry (2004) include corporate capitalism and the modern nation-state in this process. Jenkins, however, suggests that human beings' capacity for imagination involves 'a predilection for enchantment' which transcends the historical moment: '[W]ithout our imaginations ... there would be nothing but ourselves and whoever was in our line of sight at the time. That would be all' (2002: 82). Thus while Romantic values are evident in some informants' accounts, these stand within a broader set of practices which act to imaginatively transcend the bland grey dust of cremulated ash, to re-enchant the residue of what is often described as the industrial process of cremation.

In what can therefore be seen as a re-enchantment of a modernist or 'breaking bonds' (Stroebe et al. 1996) approach to disposal and memorialization, our informants describe disposing of ashes in natural landscapes and the elements of water and wind; a desire for a strongly emotional relationship with the dead; a sanctioning of visits to sites of disposal and their elaborate cultivation; and the hope of reunification with a loved one, either in an afterlife or quite commonly via the mingling of ashes.

These values are evident in new beliefs and practices associated with other lifecourse transitions: for example, campaigns for 'natural' birth, which stem from the 1930 s (see Dick-Read 1933), but were taken up in the 1990s by an increasingly politicized National Childbirth Trust; a romantic elaboration of the wedding during the late 1990s, involving highly individualized ceremonies in exotic locations; and in 1991 the establishment of the Natural Death Centre in London. Indeed once the apparently extraordinary events precipitated by the death of Diana, Princess of Wales, in 1997 are viewed within this wider context of re-enchantment, their scale and intensity become less surprising. These included large-scale informal acts of mourning such as the crowding of flowers, toys, and personalized posters into the sites associated with her life. Of the final destination of her corpse, Jupp and Walter (1999) note that its burial on a private island is reminiscent of Rousseau's tomb in the carefully staged 'natural' environment of the lake island of Ermonville - even though its explicit purpose was to protect her corpse from intruders. Popularly regarded as the late twentieth century's most 
magically - and tragically - romantic heroine, Diana, Princess of Wales, was not, therefore, interred in a conventional burial site. Instead her body left the metropolis for her family's country park, on land consecrated for burial only two days previously (Davie \& Martin 1999). Since the media made this 'private' disposal of Diana's body highly 'public', they acted to legitimate a break with convention, one which our data suggest was already taking place at more private and individual levels.

\section{Symbolic re-integration}

Thus far we have explored the cultural, social, and legislative context of independent ash disposal. Once ashes are removed from a crematorium, their subsequent disposal is no longer bound by concerns about the integrity of the body and the stability of community-based sites of disposal. Some sets of ashes are released to quite literally 'blow in the wind', and other practices evidenced in our data, such as the dividing of ashes between different sites, suggest a metaphoric freedom from the ties of traditional Christian beliefs and family or community-based locales. Within a cultural and historical context where the commonplace re-enchantment of the everyday world now sanctions beliefs and practices which might, for example, demonstrate an ongoing 'romance with romanticism' (Stroebe et al. 1996), the material fluidity of cremulated ashes and an absence of restrictive legislation enable a new growth of informal ritualization around the remains of the dead.

What we suggest, however, is that while contemporary practice is no longer bound by a traditional fixity of place, or indeed social relationships or collective memorializing, the diversity of strategies reported by interviewees do demonstrate a common concern to achieve symbolic forms of re-integration or coherence. That is to say, the choices being made allow the deceased, and their mourning, to be more firmly re-inscribed within the times and spaces which constituted their life history and social identity - using the cultural legacies and social and technological resources currently available. This scope for meaning-making was found by many to be lacking within a site of collective disposal such as their local crematorium's garden of remembrance. For example, when asked why she had not left her husband's ashes at the crematorium, a Nottingham widow replied, 'Well, it perhaps would be, how shall I put it, diluting of the essence? Which again would have been very different than scattering the ashes in a place that I knew Tom loved'. This point was reinforced by other interviewees, including a young man from Glasgow who reflected that scattering ashes at a formal public site for ash disposal felt impersonal and impermanent. Indeed when pressed about his reasoning, he explained, 'Personally I think, well do something, go back to the places that meant something to you and them, and be a bit sentimental if anything'. Recognizing that this is often for the good of the bereaved relatives rather than the deceased, he went on to recall how at the funeral of a close friend, the deceased's brother had confided to him that that even at that early stage they had special plans for the ashes, other than the garden of remembrance, stating, 'Aye he's not coming back, and we'll be doing something, later on down the line, something a bit more like for us, for the permanence of it, something a bit more permanent'.

Having said this, ashes are commonly disposed of in public places such as graveyards, cemeteries, and crematoria grounds, but no longer of necessity those at which the body was cremated. Reasons for this choice include the presence of family graves and the proximity of a burial ground for visits and tending the site. The small space required to formally inter ashes in a grave, or illicitly scatter them on the surface, makes 
otherwise full ancestral burial plots re-usable. For some survivors, the public cemetery represents a well-bounded spot in which to situate the ashes, whereas for others it provides a neutral location, free from ownership conflicts precipitated by decisionmaking after a family death. For example, Roberta Buswell, ${ }^{2}$ a woman from Glasgow, left six adult children who fought over what should happen to her ashes. Her middle son contested both his eldest sister's demands that they be placed in the plot bought for herself and her husband, and an alternative suggestion that they be interred beneath a rose bush at a Scottish island the mother would visit. Eventually he persuaded the majority of his siblings to purchase a new family plot in a cemetery accessible for them all.

Parks, football grounds, and parts of the natural landscape, such as beauty spots, tend to be chosen because of their previous significance for the deceased. Sites such as the Peak and Lake Districts, Loch Lomond, and the Yorkshire Moors were often selected for the memories they carry of family holidays, walking tours, or honeymoons. Football clubs throughout the UK are familiar with fans' requests to scatter ashes on their pitches. Several initially allowed scattering on the centre circle, but as demand has intensified, they have restricted this to the edge of the pitch or set up nearby gardens of remembrance. One Sunderland family we interviewed had arranged for three of its members to be scattered in the grounds of Sunderland AFC. Speaking of the first ceremony, Freda Douglas, the sister of the deceased, described her brother's passion for Sunderland United despite living away, his frequent calls home for the football score regardless of where his job as an oil contractor took him. Freda recalls,

\footnotetext{
So we had his funeral in London and brought his ashes back up here, and as soon as I'd heard he'd died, straight away, you know, I mean after getting over the shock, straight away I said we've got to spread his ashes at Roker Park, there's no ifs or buts.
}

Similarly, another Sunderland informant described honouring his daughter's request to have her ashes scattered in the centre circle of the Roker Park ground just before it was sold off. Asked if the site's redevelopment had concerned him, he replied that, on the contrary, the centre circle itself had been moved in its entirety to the new Stadium of Light and he believed the ashes would have transferred with the turf.

Ashes may also be located in private places such as the home, where the bedroom, the lounge, and the wardrobe may provide temporary storage locations, prior to a final decision, or the mingling of ashes with those of a surviving relative, once they too have died. Ivy Canterbury, a widow from Nottingham, related how her husband's ashes had been moved around her living room over time. Initially given public prominence on the windowsill, the sensitivities of visitors gradually persuaded her to relocate them more privately. For a while they were kept in the space between an armchair and the wall where her daughter would sit hugging their wooden casket when she visited. Now Ivy has moved them to the bottom of a glass-fronted cabinet in the far corner of the room. Other informants have also described the comfort of having the ashes in close proximity. A divorced businesswoman felt reassured by keeping the ashes of her parents in her bedroom, whilst a dock worker from Glasgow placed his father's urn on his mantelpiece for several weeks in order to focus his reflections on their often traumatic relationship. Eventually the ashes were moved into the less visible but still auspicious location of his record cupboard. Likewise a retired Sunderland piano-maker said, 
so, perhaps it's coloured by my religious beliefs of life after death, not particularly in the physical form but in a mental form, and I honestly believe that a love as strong as ours is rather like energy, can be spent elsewhere but not destroyed. I think they're the only valid reasons I've got for keeping my wife's ashes at home.

These choices suggest a desire for connection with the deceased via the resources of spatial location and material practice, the unification which Turner (1969: 48) describes as the symbolic goal of ritualized meaning-making practices. On some level, therefore, both the living and the dead are made to co-exist within a shared landscape.

Another private site is the garden, and here moveable features such as a plant pot, bird bath, or indeed stout polythene container ensure that any subsequent house move need not involve a separation from these remains. Finally, the bodies of survivors themselves can be sites of 'disposal', if, for example, ashes are incorporated into jewellery or placed in sachets in wallets. One informant wore such jewellery only when she left her home, the ashes becoming most potent at times of her mobility and an associated sense of vulnerability when going out alone.

Thus, while mechanisms and sites of disposal vary, at the level of meaning, survivors' choices often enable the symbolic creation of coherence: for example, via the integration of different periods of the deceased's and the family's life-course, of separate generations, or of the deceased's material remains and the home - and indeed the body - of a survivor. So while the physical body may be quite literally scattered to the four winds, the social identity of the deceased is sustained, its constituent elements, such as places lived in or visited, relationships or pastimes, all being reintegrated through new forms of disposal and memorialization (see Hallam et al. 1999). The body's dispersible ash residue therefore enables symbolic social integration, even while a previous valorizing of bodily integrity no longer holds sway.

These points can be traced through an in-depth case study of one family's response to the death of their grandmother. At the time of interview, her ashes were in their home, pending a decision about their final destination which was very much in process. Place had considerable rhetorical power as mother and daughter contested one another's prospective plans, yet the meanings mobilized in relation to place were diverse. While shared cultural values were evident, the family described itself as without religious beliefs. How their values might coalesce in particular ritual forms was not clear for these informants. Not only did mother and daughter disagree, but neither could understand her own feelings or how to express them. During the interview they asked whether their responses were 'weird' and whether others had said similar things. As has been argued, the 1970 s seem to mark a watershed in terms of how the living understand their relationship with the dead, and this case study exemplifies the more deliberate and self-reflexive meaning-making processes referred to above.

The analysis of the case study involves asking about the cultural resources being drawn upon, the ways in which place figures within decision-making, and the extent to which this family's beliefs and practices reflect a broad trend towards the re-enchantment of the everyday world, following a loss of traditional religious faith and industrial standardization. Roach uses the concept of surrogation to argue that 'into the cavities created by loss through death or other forms of departure, I hypothesize, survivors attempt to fit satisfactory alternates' (1996: 2). However, surrogation is rarely entirely successful, he says, for 'the fit cannot be exact. The intended substitute either cannot fulfill expectations, creating a deficit, or actually exceeds them, creating a surplus' (1996: 2). This, he argues, is unsurprising since even time-honoured ritual, or 
tradition, is never ever 'repeated': '[N]ew traditions may be invented and others overturned. The paradox of the restoration of behaviour resides in the phenomenon of repetition itself: no action or sequence of actions may be performed exactly the same way twice; they must be reinvented or recreated at each appearance' (1996: 29).

As argued, the mourning for Diana, Princess of Wales, reflected many of the themes evident in nineteenth-century Romanticism. Indeed, the complex circumstances of Diana's death had led Maura, the mother within our case study family, to think critically about how she might respond to the death of Nan, the grandmother. She said of Diana:

The decision then that she'd go and all the family rivalry and the politics of the family came up, she got taken to this like lonely island ... this kind of mausoleum, so it just makes you think about it in that way, it almost seemed like a whole family's, the politics of it, the fall out of it, bad blood in the family, what are you going to do about something?

Throughout the entire interview, this question of 'what are you going to do about something?' preoccupied both Maura and her daughter, Sylvia.

Nan, the grandmother, was Spanish. After the Second World War she came to Nottingham, where she died in September 2003. Throughout the twenty-five years of her widowhood she lived with her daughter, Maura, and her granddaughter, Sylvia. Maura's husband left the household soon after Sylvia was born, and Nan became mother to Sylvia too, while Maura went out to work. In its embodied form, the intense emotional relationship between Nan, Maura, and Sylvia was severed by Nan's death. However, the residue of her corpse - the ashes - was returned to their shared home, a material substance which sustained Nan's social presence and the bonds between the three women. Maura talked lengthily of her difficult relationship with her mother, a love-hate connection which she likened to 'Steptoe and Son', even in the details of her mother's insistence on wearing threadbare charity shop clothing, the smell she created in the kitchen when cleaning pet food cans for recycling, and her willingness to allow her many pets up onto the work surfaces. Maura's sister, Freda, had had an even more difficult relationship with Nan, resulting in a seven-year silence between the two branches of the family. Like the Windsors and the Spencers, therefore, this family was seeking to respond appropriately to the death of someone with a powerful, yet troubling presence.

Containment within the spaces of the home characterized the relationship between these women, confining them in uneasy bodily proximity to one another. When Nan's health declined, Maura provided intimate care, though with difficulty:

I'd start sort of gentle and then because I was in a mood or fed up with something ... I'd end up scrubbing her a bit hard. She'd be going 'ouch, ouch'.

Maura would respond with:

Oh shut up. Never mind 'ouch' ... this is pay-back time ... you used to scrub us like that when we were kids.

The night after Nan died, however, Maura recollected that 'we slept in her bed. It was all so surreal. We had not been eating. Maura put on Nan's used pyjamas, for the first time welcoming the smell of her body - and tried to take in what had happened. 
This complex relationship clearly preoccupied Maura and, with its tensions and demands in the past, she drew on a Romantic concern with the uniqueness of the individual. Refusing the collectivity of a traditional site of disposal, the municipal cemetery's garden of remembrance, Maura said: '[Nan] wouldn't want to be ... with a load of other dead people up there ... sort of moping around'. This negative choice opened a range of positive choices within which the issue of place proved paramount. Despite the three women's problematic proximity, Nan in fact spent her days out and about, well known in the local community. Whether focus and coherence could be achieved by retaining her ashes close to home, or by locating them in one of the public places which Nan frequented, was a dilemma which drew out the competing opinions of Maura, Sylvia, Nan's surviving sisters, and Nan herself.

With regard to the latter, Nan had requested that her ashes be scattered in their garden alongside her many pets' graves. Her sisters' support for this view was legitimated by the authority of 'Nan's wishes'. Maura, however, countered this with the persuasive notion of 'focus'. Since their garden may be subject to a compulsory purchase order to make way for a by-pass, Maura could be moving. As a result strangers 'might move in, build an extension and so what happens then?' she said. Not only would the ashes be disturbed, but the family's relationship with Nan would lack a focus: 'Where do we go?' she said, 'Yes you have your memories but where do you go to think and reflect. On a birthday? Yeah, you could sit in your living room and think about them, but there's that almost physical need - that's why a lot of people have benches, trees, etc.. Her daughter, Sylvia, countered this by invoking 'Nan's choice'. In her view, Nan would prefer a memorial area with a bench in the shopping precinct where she spent her time, annoying local traders by feeding the pigeons. Maura opposed this on the grounds of its impermanence. The shopping centre might be redeveloped so the park might be a more permanent location, one of Nan's favourite dog-walking haunts.

Along with the risk of disturbance is the question of the integrity of the ashes. Maura wanted to retain a portion to mingle with her own, an evocation of Romantic notions of post-mortem reunification. She explained her desire for reunification, saying 'we couldn't be close in life but perhaps this is me making up to her'. Though she suspected that Nan might 'turn in her jar' at this prospective erasure of bodily boundaries, she made her point strongly, albeit with humour. Sylvia, however, thought her mother was being selfish.

Despite concerns about finding a location where permanence, proximity, and therefore focus were safeguarded, Maura also said: 'I want to be able to let her be that free spirit that she wants'. Here Sylvia agreed, adding, 'Yeah, 'cos that's the point why she wasn't buried because you know to sort of think forever be sort of underground ... or in a coffin, God, she'd have hated that, but to be in the air .... Pending a decision, however, Nan's ashes remained in their polytainer, inside a velvet bag, on a chair at the dining table. Maura had put Nan's old woolly hat on top of the bag with her 'fags' and lighter ready on the table. Where Nan's cats had once coated her clothing in their fur, now they weaved about her ashes, providing a similar layer of organic material. Animated in this way, Nan retained a strong social presence in the home: Maura greeted the ashes when she returned home, and told the dogs to look after them whilst she was out.

Although these practices were inspired by powerful feelings, and indeed Maura stressed the comfort she received, they failed to match with any traditional or collective belief system. As an atheist, Maura did not believe that Nan's spirit resided in the ashes. Yet she felt that 'it's her bones, it's her matter ... I don't think it's her spirit, I think it's 
my mum that's there. The mum I lived with and looked after not very well towards the end'. For Maura the ashes were the physical residue of Nan, the remains of her mother in her habitual cagoule, charity shop fleece, Pringle sweater, Liberty skirt, and thick tights: 'So what I am holding there, in that jar, is ... what I saw my mum in that coffin, in the clothes we put her in because that's what I remembered her in'.

Crucially, it was the materiality of Nan's residue which Maura drew on when defending her practices:

\footnotetext{
Her being in that jar is something that I can pick up. I have used it as a comfort, I've slept with it a couple of nights, put it next to me when I've been watching the television when I've felt vulnerable and really down. There will come a point when I will be able to let her go, but because we weren't a very tactile family and had a dysfunctional relationship, I feel I am doing now in death perhaps what I would have done with her in life. So if it's just to love her or hug her, I am doing it with her jar ... She would probably say 'Oh my God what are you doing that for?' but 'Bugger you, love, here's a kiss, I'm doing that, like I should have done in life'.
}

Maura's desire for not only continuing but also enhanced bonds with her mother was evident when Sylvia described a friend's mother keeping her husband's ashes in the wardrobe and taking them out for occasional conversation. Maura retorted: 'That's just like shutting them out. If you are going to have them they have got to be in that room with you ... I wouldn't have my mum as an ornament, sitting on the mantelpiece as my mum never sat on the mantelpiece.' Though she anticipated some kind of final disposal, Maura said she would not 'release' the ashes until she had made her peace with them.

Not only was the choice of location contested, therefore, but their meaning too evoked powerful, yet almost irreconcilable responses. Thus Maura noted that Sylvia thinks she is being macabre; and when she brought a friend around, he almost recoiled when shown the ashes. However, some visitors would greet the ashes confidently. Other informants described a similar diversity of responses: some dealt with these by joking or telling a story about the deceased; some, as in the case of Ivy Canterbury, gradually moved the ashes into more private places in the room as public disapproval became evident.

In sum, concerns with release and freedom evidenced in the case of Nan might suggest that fixity, focus, and permanency are no longer an issue within post-cremation ritualization. However, as shown, these criteria are of the utmost importance when Maura and Sylvia were selecting the final location of Nan's ashes. Maura could not countenance putting her mother in a location which might be disturbed - whether a house, a garden, or a bench. Instead she yearned for a significant landscape that was unlikely to change in her lifetime, one which would allow for the re-integration of Nan's social identity and the events which made up her life-course.

\section{Conclusion}

This article has identified the material or sensory properties of human ashes which resource both symbolization and the generation of new ritual practices. Since cremation became the dominant form of disposal in the United Kingdom in the late 1960s, there has been a gradual decrease in the numbers of people willing to leave ashes behind in the public and anonymous grounds of crematoria. This has taken place alongside a proliferation of new mourning and memorialization strategies as individuals and organizations have begun to express dissatisfaction with the existing, narrow range of choices available and critically challenge professional attitudes and practices 
surrounding death, dying, and bereavement. This can clearly be seen in examples such as the growth of the hospice movement, the post-1980s introduction of funerals and identification materials such as birth certificates for stillborn babies, or, as discussed earlier, the paradigmatic shift from stage- or task-based models of grief to an acceptance of 'continuing bonds' theory within much of the therapeutic literature. The popularity of personalized memorialization intensified, however, in the 1990s, as cemeteries became filled with greetings cards, toys, solar cell lights, and wind chimes, the internet was peppered with obituary web pages, and sites of roadside accidents or murder spots were marked by wreaths and private messages to the deceased.

Within the context of these more general trends, it is possible to identify the emergence of significantly changing post-cremation ritualization practices in the UK. However, the corpse's dusty residue has only recently been recognized for its potential for private disposal and memorialization. Its stable yet malleable form allows for mobility and division; the dead, symbolized by their very material remains, can return home as ancestor, ornament, guardian, or companion, be 'released' in a ceremony of scattering in a favoured location, or kept safe and together within a family grave or garden. They can provide forgetfulness, forgiveness, or freedom through dispersal, or a 'focus' where relatives can return and gather their thoughts. Indeed one or even all of these options are often chosen for a single set of ashes, sometimes creating conflict or, in other cases, easing it. Important for many is the temporal advantage. Unlike the 'wet' corpse, decisions about ashes can be postponed until a more opportune moment or state of mind - a fact attested to by the ashes uncollected in funeral directors' offices. Until recently, the act of cremation formed the final stage in disposal, if perhaps not memorialization. It is clear, however, that as ever more people take ashes away from crematoria, a prolonged period of ongoing ritualization is frequently taking place following the death of someone close, with the cremated remains as a primary, if often private, source of momentum and activity.

This article has therefore argued that contemporary trends towards the reenchantment of the everyday world (Jenkins 2000; 2002) provide a context within which individuals are drawing upon cultural repertoires which include, for example, the legacy of nineteenth-century Romantic values. As we have argued, the beliefs and practices described by our informants constitute a death-related case study which can be situated within far broader processes of social change. These include challenges to modernism's scientific and bureaucratic rationality, as reflected in social movements which range from campaigns for 'natural' birth and death, through to the activities of environmental lobbies, at local and global levels. Such challenges are also evident in a therapeutic bereavement literature which reflects the vociferously expressed views of particular categories of bereaved people who have resisted materialist conceptions of death as the end of social and emotional relatedness.

With more than half of all ashes removed from crematoria for independent disposal, and with cemeteries now displaying a growing uniformity of 'individual' informal memorializing, it is evident that grief itself constitutes a key site from which an existing order of professional expertise and regulation has been challenged. Anthropologists, from Turner (1974) to Seremetakis (1991), have made reference to the 'power of the weak', to the capacity of 'affective enclaves' and 'communities of pain and healing' (Seremetakis 1991), to bring about disruption and change within dominant orders. None the less, the innovative approaches described in this article are themselves likely to become 'encompassed within the system building, generalizing 
metanarratives characteristic of modernity that recent theorists set out to eschew when they speak of moving from the narrative of grief to "how people experience and live their lives"' (Small 2001: 34-5). In other words, a more individualized approach to death and dying is itself likely to take on more formal and indeed collectively shared qualities over the course of time. If we look back to the nineteenth century, Morley argued that Romantic approaches to loss eventually led to a situation where 'the display of feeling soon became a necessary part of the social equipment of every polite person and, as such, it percolated to the lower classes. Grief was a preeminent feeling; even where there was cause for grief, it seems that it often became necessary to force it' (1971: 17).

If, as Nan's family exemplified, those who are currently negotiating their path through a widening range of disposal and memorializing choices experience confusion and indeed interpersonal discord at a time of emotional suffering, it is none the less the case that as new beliefs and practices continue to develop, the twenty-first century is likely to witness the establishment of an altered yet eventually more shared culture of death. While Walter acknowledges the postmodern centrality of choice, he also makes the point that 'doing it yourself is therefore possible, but only in company' (1994: 189).

\section{NOTES}

We are grateful to the Economic and Social Research Council for their support for our project: 'Environments of memory: changing rituals of mourning and their personal, social, and emotional implications'.

${ }^{1}$ See http://www.environment-agency.gov.uk/aboutus/.

${ }^{2}$ Pseudonyms have been used for all the informants we refer to by name, in order to protect confidentiality.

\section{REFERENCES}

Arber, R. 2000. Disposal of cremated remains: a European perspective. Unpublished report to the International Cremation Federation by Roger Arber, Secretary-General.

Bennett, G. \& K.M. Bennett 2000. The presence of the dead: an empirical study. Mortality 5, 139-57.

Cremation Society of Great Britain 1974. The history of modern cremation in Great Britain from 1874. Maidstone: Cremation Society of Great Britain.

Danforth, L.M. 1982. The death rituals of rural Greece. Princeton: University Press.

Davie, G. \& D. Martin 1999. Liturgy and music. In The mourning for Diana (ed.) T. Walter, 187-98. Oxford: Berg.

Davies, D. \& A. Shaw 1995. Reusing old graves: a report on popular British attitudes. Crayford: Shaw \& Sons. Dick-ReAd, G. 1933. Natural childbirth. London: Heinemann.

Foucault, M. 1977 [1969]. The archaeology of knowledge (trans. A.M. Sheridan Smith). London: Tavistock. Francis, D., D. Kellaher \& G. Neophytou 2000. Sustaining cemeteries: the user perspective. Mortality 5 , 34-52.

- -2001 . The cemetery: the evidence of continuing bonds. In Grief, mourning and death ritual (eds) J. Hockey, J. Katz \& N. Small, 226-36. Buckingham: Open University Press.

- - -2005 . The secret cemetery. Oxford: Berg.

Freud, S. 1957 [1917]. Mourning and melancholia. In The standard edition of the complete psychological works of Sigmund Freud, vol. 14, 243-58. London: Hogarth Press and Institute of Psycho-Analysis.

Hallam, E., J. Hockey \& G. Howarth 1999. Beyond the body: death and social identity. London: Routledge.

Hertz, R. 1960 [1907]. Death and the right hand (trans. R. Needham \& C. Needham). Aberdeen: Cohen \& West.

Horrox, R. 1999. Purgatory, prayer and plague: 1150-1380. In Death in England: an illustrated history (eds) P. Jupp \& C. Gittings, 90-119. Manchester: University Press.

Howes, D. 1991. The varieties of sensory experience. Toronto: University Press.

Huntington, R. \& P. Metcalf 1979. Celebrations of death: the anthropology of mortuary ritual. Cambridge: University Press. 
Jalland, P. 1999. Victorian death and its decline: 1850-1918. In Death in England: an illustrated history (eds) P. Jupp \& C. Gittings, 230-55. Manchester: University Press.

Jenkins, R. 2000. Disenchantment, enchantment and re-enchantment: Max Weber at the millennium. Max Weber Studies 1, 11-32.

2002. Foundations of sociology. Basingstoke: Palgrave Macmillan.

Jupp, P. \& T. WAlter 1999. The healthy society: 1918-1998. In Death in England: an illustrated history (eds) P. Jupp \& C. Gittings, 256-82. Manchester: University Press.

Kellaher, L., D. Prendergast \& J. Hockey 2004. Resistance, renewal or reinvention: the removal of ashes from crematoria. Pharos International 70: 4, 10-13.

Klass, D., P.R. Silverman \& S.L. Nickman 1996. Continuing bonds: new understandings of grief. Washington, D.C.: Taylor \& Francis.

LitTlewood, J. 2001. Just an old-fashioned love song or a 'harlequin romance'? Some experiences of widowhood. In Grief, mourning and death ritual (eds) J. Hockey, J. Katz \& N. Small, 82-94. Buckingham: Open University Press.

Macnaghten, P. \& J. Urry 1998. Contested natures. London: Sage.

Morley, J. 1971. Death, heaven and the Victorians. London: Studio Vista.

PARKes, C.M. 1972. Bereavement: studies of grief in adult life. London: Tavistock.

Prothero, S. 2001. Purified by fire: a history of cremation in America. London: University of California Press.

Riches, G. \& P. DAwson 2000. An intimate loneliness: supporting bereaved parents and siblings. Buckingham:

Open University Press.

RoAch, J. 1996. Cities of the dead. New York: Columbia University Press.

RugG, J. 1999. From reason to regulation: 1760-1850. In Death in England: an illustrated history (eds) P. Jupp \& C. Gittings, 202-29. Manchester: University Press.

Seremetakis, C.N. 1991. The last word: women, death and divination in inner Mani. Chicago: University Press. Small, N. 2001. Theories of grief: a critical overview. In Grief, mourning and death ritual (eds) J. Hockey, J. Katz \& N. Small, 19-48. Buckingham: Open University Press.

Stoppard, T. 1968. Rosencrantz and Guildenstern are dead. London: Faber \& Faber.

Stroebe, M., M. Gergen, K. Gergen \& W. Stroebe 1996. Broken hearts or broken bonds? In Continuing bonds: new understandings of grief (eds) D. Klass, P. Silverman \& S. Nickman, 31-44. Washington, D.C.: Taylor \& Francis.

— \& H. Schut 1999. The dual process model of coping with bereavement: rationale and description. Death Studies 23, 197-224.

Turner, V. 1969. The ritual process. Harmondsworth: Penguin. 1974. Dramas, field and metaphors. Ithaca: Cornell University Press.

Walter, T. 1990. Funerals and how to improve them. London: Hodder \& Stoughton.

1994. The revival of death. London: Routledge.

1996. A new model of grief: bereavement and biography. Mortality 1, 7-26.

Weber, M. 1930 [1904-5]. The Protestant ethic and the spirit of capitalism (trans. T. Parsons). New York: Charles Scribner \& Sons.

Willis, R. \& P. CUrry 2004. Astrology, science and culture: pulling down the moon. Oxford: Berg.

Worden, J.W. 1982. Grief counselling and grief therapy: a handbook for the mental health practitioner. New York: Springer.

\section{Autant en emporte le vent ? Identité, matérialité et devenirs des cendres humaines}

Résumé

Les auteurs s'interrogent sur la pratique, récemment apparue au Royaume-Uni, de retirer les cendres des défunts des crématoriums et se demandent si elle a donné naissance à des rituels entièrement nouveaux de disposition des corps, ou si les pratiques contemporaines constituent une appropriation des valeurs et croyances romantiques de la fin du XIX ${ }^{\mathrm{e}}$ siècle. À partir des observations obtenues lors d'une grande étude empirique menée parmi les professionnels et les profanes impliqués dans l'enlèvement des cendres, les auteurs étudient les potentialités des cendres comme vestige du corps matériel et mobile, et se demandent si elles permettent des stratégies de disposition qui ne tiendraient plus compte des problématiques d'espace et de lieu liées notamment aux cimetières traditionnels. 
David Prendergast is currently engaged in ethnographic research on ageing and independent living in the EU and China with Intel's 'Global Ageing Experience Project'. He is author of From elder to ancestor: old age, death and inheritance in modern Korea (Global Oriental, 2005) and co-author of No place like home: domiciliary care services for older people in Ireland (Liffey Press, 2006).

Ethnographic Enterprises, 22 Luttrell Park Crescent, Castleknock, Dublin 15, Eire. D.Prendergast@yahoo.co.uk

Jenny Hockey trained as an anthropologist and is Professor of Sociology at the University of Sheffield. Her research interests include ageing, death, dying, disposal, and bereavement, and her publications in this field include Death, memory and material culture (Berg, 2001), co-authored with Elizabeth Hallam at Aberdeen University.

Department of Sociological Studies, University of Sheffield, Elmfield, Northumberland Road, Sheffield STo 2 TU, UK.J.Hockey@sheffield.ac.uk

Leonie Kellaher is a principal research fellow at London Metropolitan University. Her research has taken an anthropological and social policy approach to the organizational, material, and built environments which people occupy - in life and in death. She is co-author of The secret cemetery (Berg, 2005; with D. Francis \& G. Neophytou).

Cities Institute, London Metropolitan University, Ladbroke House, 62-66 Highbury Grove, London N5 2AD, UK. Leonie@kellaher.co.uk 